\title{
Demografia dos povos indígenas em perspectiva internacional
}

\author{
Ricardo Ventura Santos*
}

AXELSSON, P.; SKÖLD, P. (Orgs.). Indigenous peoples and demography: the complex relation between identity and statistics. Nova York: Berghahn Book, 2011 (ISBN 978-0-85745-000-5).

O tema da demografia de minorias étnicas, particularmente de populações ditas "nativas" ou “indígenas", tem crescentemente atraído a atenção não somente de pesquisadores dos campos dos estudos populacionais, sociologia e antropologia, mas também de agências nacionais e internacionais envolvidas com questões censitárias. Para exemplificar com um contexto próximo, os censos decenais realizados na América Latina vêm, nas últimas décadas, expandindo significativamente a coleta de dados acerca das etnias indígenas. No plano transnacional, há esforços por parte da Organização das Nações Unidas e de outras agências de cooperação no sentido de estimular a sistematização e comparabilidade de dados demográficos para povos indígenas das diversas partes do mundo. 0 caso brasileiro é bastante ilustrativo dessa tendência, com a inclusão, a partir de 1991, da categoria "indígena” como uma das opções no quesito sobre cor/raça dos censos demográficos. Nos censos seguintes, com destaque para o de 2010, houve uma notável ampliação do leque de perguntas relativas aos indígenas, incluindo pertencimento étnico, línguas faladas, residência ou não em terras indígenas, características específicas de moradia e saneamento, entre outras.

Seja no Brasil, seja na América Latina ou em qualquer país do mundo com presença de povos indígenas, as iniciativas de inclusão de perguntas de recorte étnico nos censos nacionais precisam lidar com a "complexa relação entre identidades e estatística”, que é precisamente o subtítulo da coletânea organizada por A. Axelsson e P. Sköld. Ambos são investigadores do Centro de Pesquisa Sami, da Umeå University, na Suécia (a propósito, Sami é a etnia indígena mais numerosa da Escandinávia). O livro resulta de uma conferência realizada em 2006 que teve por objetivo debater questões teóricas e metodológicas, assim como no plano das políticas públicas, sobre a demografia dos povos indígenas em uma perspectiva

\footnotetext{
* Escola Nacional de Saúde Pública/Fundação Oswaldo Cruz - Ensp/Fiocruz, Rio de Janeiro-RJ, Brasil (santos@ensp. fiocruz.br).
} 
global. Ou, como expresso pelos organizadores, o volume aborda temas concernentes às relações entre classificações demográficas, políticas governamentais, posicionamentos indígenas e identidades étnicas (p. 12).

Com 16 capítulos, além de uma Introdução e um Epílogo, o livro oferece um panorama amplo e, ao mesmo tempo, nuançado acerca dos desafios de representar, por meio de dados quantitativos, identidades indígenas em contextos censitários os mais diversos, no passado e no presente. Ainda que tivessem por intuito produzir um panorama mundial, os organizadores reconhecem que, em decorrência de suas respectivas filiações institucionais e interesses de pesquisa, há uma importante concentração de trabalhos relativos ao norte da Europa e ao campo de demografia histórica. Não obstante, o volume abriga um conjunto expressivo de estudos de caso, de modo que, já em seu nascimento, se impõe como uma referência para os estudos sobre demografia indígena.

Como todo trabalho de fôlego, a diversidade temporal, geográfica e analítica das contribuições coloca um desafio para os leitores. Isso porque os capítulos, em sua ampla maioria, se caracterizam pela densidade descritiva e analítica, de modo que não é tarefa sempre fácil transitar por temporalidades e contextos sócio-históricos tão variados. Por exemplo, no percurso da leitura, os leitores vão desde um mergulho em uma perspectiva eminentemente sociológica acerca das identidades Maori na Nova Zelândia na atualidade (capítulo 2) até um estudo sobre as categorias utilizadas em censos na América espanhola, e Colômbia em particular, nos séculos XVIII e XIX (capítulo 3); desde os desafios de construção de tabelas de vida para populações indígenas nos EUA no início do século XX (capítulo 4) até uma análise sobre as populações nativas do Canadá segundo o censo de 1891 (capítulo 5); desde um olhar sobre categorias utilizadas nos países da região do Báltico, no norte da Europa, para a contagem das minorias étnicas entre o século XIX e os dias atuais (capítulo 15), até debates recentes sobre minorias étnicas ditas indígenas no contexto britânico (capítulo 16). A parte central do livro, dos capítulos 6 a 11, apresenta estudos de caso, históricos e atuais, sobre etnias indígenas (com destaque para os Sami) em países como Suécia e Noruega.

É importante destacar que os organizadores realizaram uma bem-sucedida e abrangente articulação entre discussão teórica e os estudos de caso que compõem o volume. Assim, na Introdução, não somente é apresentada uma substantiva reflexão sobre as formas e desafios com que categorias socioantropológicas, como cultura, tendem a ser quantificadas por dados demográficos, como também são abordadas as dificuldades de se estabelecer uma definição de "indígena" que se aplique em uma escala internacional mais ampla. Por sua vez, o espírito do "Epílogo" é o de trazer uma reflexão sobre as consequências decorrentes da inclusão de categorias referentes aos indígenas em levantamentos censitários, tais como as práticas de enumeração, as respostas indígenas às ações governamentais voltadas para o registro de dados demográficos e os desafios de caracterização das identidades étnicas indígenas em escala internacional. Desse modo, em sua ampla diversidade temporal e sócio-histórica, discussão teórica sobre as políticas de identidade e enfrentamento dos desafios práticos de 
reverter a invisibilidade demográfica de indígenas em contextos nacionais caminham lado a lado ao longo dos capítulos.

Alguns anos atrás, Marshall Sahlins, conhecido antropólogo da Universidade de Chicago, publicou um texto no qual discute o que denominou de "pessimismo sentimental" da antropologia no contexto das transformações culturais experimentadas pelos povos indígenas. Segundo o autor, a antropologia é "talvez a única disciplina fundada no princípio da coruja de Minerva: ela começou como uma disciplina profissional justamente quando seu objeto de estudo já ia desaparecendo" (SAHLINS, 1997, p. 42). Um dos argumentos de Sahlins é que, longe de uma visão de irrevogável desaparecimento (daí a ideia de pessimismo), culturas e identidades indígenas, em muitas situações, tendem a se fortalecer com o desenrolar do chamado processo de globalização. Em larga medida, ao se terminar a leitura de Indigenous peoples and demography, fica para o leitor a forte sensação de que a imagem da "coruja de Minerva" tampouco se aplica ao emergente campo da demografia dos povos indígenas. Se, por um lado, há inequívocas evidências de que os indígenas experimentaram brutais níveis de mortalidade, levando ao desaparecimento de um sem-número de povos a partir da expansão colonial dos últimos séculos, por outro, os interessados no tema da demografia indígena precisam enfrentar, com otimismo, o enorme desafio de registrar e sistematizar as dinâmicas populacionais nativas, que se expressam no bojo de processos étnico-culturais os mais diversos em todo o mundo.

\section{Referências}

SAHLINS, M. O "pessimismo sentimental" e a experiência etnográfica: por que a cultura não é um "objeto" em via de extinção (parte I). Mana: Estudos de Antropologia Social, v. 3, n. 1, p. 41-73, 1997.

\section{Autor}

Ricardo Ventura Santos é Ph.D em Antropologia. Pesquisador titular da Escola Nacional de Saúde Pública/ Fundação Oswaldo Cruz - Ensp/Fiocruz e professor associado IV do Departamento de Antropologia, Museu Nacional/Universidade Federal do Rio de Janeiro - UFRJ. 
